\title{
ANALYSIS OF OLYMPIC EDUCATION THEORETICAL READINESS OF FUTURE PHYSICAL CULTURE TEACHERS
}

Bondar A.A.

Kamenetz-Podolsk National University

\begin{abstract}
Purpose: analysis of Olympic knowledge system in future physical culture teachers. Material: in the research 1804 year students of physical culture faculties participated. Results: it was found that students' theoretical knowledge level in the sphere of Olympic movement corresponds to low. It was confirmed that system of Olympic knowledge is an integral part of future physical culture teachers' readiness for Olympic education of schoolchildren. It was found that in the process of knowledge formation in students it is necessary to consider theoretical material on Olympic education, acting academic programs for pupils of comprehensive educational establishments. Conclusions: students have low level of knowledge in sphere of Olympic movement (general indicator was 57.4\%). It weakens effectiveness of skills, knowledge and motivation's formation in realization of schoolchildren's Olympic education.
\end{abstract}

Key words: Olympic education, knowledge, students, test.

\section{Introduction}

At the beginning of $21^{\text {st }}$ century one of the most important directions of modern Olympic movement Olympic education of children and students became. In our country, for recent decade the system of Olympic education has powerfully developed and formed; it is directed at formation of harmoniously developed personality. All it is achieved by acquiring of knowledge, skills and abilities, development of interests, value orientations. The received knowledge is based on humanistic ideals and values of Olympic movement and is a part of general education.

Implementation of Olympic education elements in educational process is studied in works of domestic authors [7, 8]. Besides, Olympic education is reflected in State standard of primary comprehensive education, in which there are requirements to the level of comprehensive education of pupils. The requirements envisage pupils' mastering of Olympic topics’ problems [State standard of primary comprehensive education. (Approved by Cabinet of ministers of Ukraine, № 462, dt. April 20 th , 2011).]. Analysis of existing academic programs for 1- and 5-11 forms shows that questions of Olympic education are a part of chapter "theoretical-methodic knowledge' on discipline "Physical culture". They are compulsory for pupils of every form [18].

Alongside with it results of foreign and domestic scientists (G. Polikarpov, G. Ragozin, V. Sergeyev, V. Yermolovaq) witness about low level of pupils' knowledge of Olympic topics. This fact is explained by insufficient quantity of qualified specialists in the field of children and students' Olympic education. [8, 11, 12, 14,]. This problem is mentioned not only in domestic but also in foreign scientific literature [19, 20, 21, 22, 23, 24]. Most of foreign authors are sure that effective realization of Olympic education is possible only with presence of highly qualified specialists. Such specialists shall have proper knowledge and skills in attracting of a personality to ideals and values of Olympic movement. Leading specialists $[7,8,10,11]$ note that main pedagogic specialists on implementation of Olympic movement's ideology in comprehensive educational establishments are graduates of specialized higher educational establishments and physical culture faculties of HEEs.

In such situation the problem of future physical culture knowledge of Olympic movement acquires first importance as well as their readiness for realization of Olympic education in the frames of future professional functioning. As on to day one of main criteria of future physical culture readiness for effective realization of Olympic education is formation level of their knowledge system in the field of Olympic movement. For confident assessment of physical culture faculties graduates' Olympic knowledge system alongside with analysis of special literature we carried out this research.

\section{Purpose, tasks of the work, material and methods}

The purpose of the research is to analyze Olympic knowledge system in future physical culture teachers.

The methods of the research: theoretical analysis and generalization of scientific-methodic literature data, testing, methods of mathematical analysis.

Knowledge level of students was determined with the help of test tasks, which were composed on the base of theoretical material on Olympic education. This material is a part of acting academic programs for 1-4 and 5-11 forms' pupils of comprehensive educational establishments [18].

Topics of test tasks consisted of three parts. The first part contained questions on history and development of Olympic Games in ancient Greece, the second - history and development of modern Olympic Games, the third - questions on history of Olympic movement in Ukraine [15].

The researches were conducted on the base of physical culture faculties of the following higher educational establishments of Ukraine: Kamenets-Podolskiy national university, named after Ivan Ogniyenko, Ternopol national

(C) Bondar A.A., 2015

http://dx.doi.org/10.15561/20755279.2015.0602 
pedagogic university, named after Vladimir Gnatiuk, Chernovitskiy national university, named after Yuriy Fedkovych, Kharkov national pedagogic university, named after Grygoriy Skovoroda. In the research 1804 year students participated.

\section{Results of the research}

The received testing results showed low level of Students' knowledge about origin of Olympic Games. For example $57.7 \%$ of students knew when the first Olympic Games took place and only $42.8 \%$ knew in what town they were conducted.

Only $43.3 \%$ of the questioned knew the program of Olympic Games of ancient Greece and $61.6 \%$ of students knew what were the awards of winners. Greece?"

$54.2 \%$ of respondent gave correct answer to question "who had right to participate in Olympic Games of ancient

The reasons of prohibitions of ancient Olympic Games were known only to $20.7 \%$ of students.

Analyzing the answers to the second part of questionnaire we noted that $67.9 \%$ of students knew who founded modern Olympic Games.

It was interesting that the place of first modern Olympic Games was known to $88.8 \%$ of students. Among them only $62.6 \%$ pointed the years of their conduct correctly.

Only $23.7 \%$ of students could call correctly the name of first president of International Olympic committee. Alongside with it the name of acting president was known only to $58.8 \%$ of the questioned.

The questioning showed that students know Olympic symbolism quite good. For example $88.3 \%$ knows the meaning of five bound rings on Olympic flag. Formulation of Olympic motto was known to $87.3 \%$ of students.

Conception "Olympism" is familiar only to $19.9 \%$ of the questioned. Such low indicator witnesses about students' unawareness of ideals and values, which are the basis of Olympic movement.

Students' questioning also showed that only 51.9\% knew about existence of the Olympic Charter.

The question "where the next summer and winter Olympic Games will be conducted?" was answered correctly by accordingly $52.9 \%$ and $51.2 \%$ of students. Only $24.8 \%$ of students knew how long modern Olympic Games last.

Analyzing students' answers to the third part of the questionnaire we noted high level of students' knowledge about history of Olympic movement in Ukraine.

The questioning results witness that most of students knew when National Olympic committee of Ukraine was formed; who was its first president (accordingly 74.8\% and 70.3\%). Acting president of NOC of Ukraine was known to $79.2 \%$ of students.

When Ukrainian team participated as teams of independent country in summer and winter Olympic Games for the first time was known to accordingly $51.6 \%$ and $68.1 \%$ of students.

The name of the first Ukrainian, who won gold Olympic medal, was pointed correctly by $74.5 \%$ of the questioned. Alongside with it the first Olympic champion of winter Games was known only to 57.9\% of students.

General indicator of correct answers in the sphere of history and modern state of Olympic movement was less than $60 \%$ (table 1$)$.

Table 1. Formation of Olympic knowledge system in students

\begin{tabular}{|c|c|c|c|c|c|c|}
\hline \multirow[t]{3}{*}{ № } & \multirow{3}{*}{ Questions to be answered } & \multicolumn{4}{|c|}{ Respondents' answers by HEEs, \% } & \multirow{3}{*}{$\begin{array}{c}\text { General } \\
\text { indicato } \\
\text { r \% }\end{array}$} \\
\hline & & Kamenets- & Ternopo & Cherno & Khark & \\
\hline & & Podolskiy & 1 & vtsy & ov & \\
\hline 1. & $\begin{array}{l}\text { Which year is considered to be the birth year of } \\
\text { ancient Greece Olympic Games? }\end{array}$ & 62,3 & 58,2 & 53,1 & 57,2 & $\mathbf{5 7 , 7}$ \\
\hline 2. & $\begin{array}{l}\text { In what city ancient Olympic Games were } \\
\text { conducted? }\end{array}$ & 49,8 & 32,6 & 40,7 & 46,1 & 42,8 \\
\hline 3. & $\begin{array}{l}\text { Name please main competitions of Olympic Games } \\
\text { in ancient Greece }\end{array}$ & 45,8 & 36,4 & 44 & 47,1 & 43,3 \\
\hline 4. & What awards the Olympic Games winners received? & 62,1 & 63,9 & 59,3 & 61,2 & 61,6 \\
\hline 5 . & $\begin{array}{l}\text { Who had right to participate in ancient Olympic } \\
\text { Games? }\end{array}$ & 62,8 & 43,7 & 51,9 & 58,4 & 54,2 \\
\hline 6. & Why Olympic Games were prohibited? & 20,3 & 21,8 & 16,8 & 24 & 20,7 \\
\hline
\end{tabular}




\begin{tabular}{|c|c|c|c|c|c|c|}
\hline \multirow[t]{3}{*}{ № } & \multirow{3}{*}{ Questions to be answered } & \multicolumn{4}{|c|}{ Respondents' answers by HEEs, \% } & \multirow{3}{*}{$\begin{array}{c}\text { General } \\
\text { indicato } \\
\text { r \% }\end{array}$} \\
\hline & & Kamenets- & Ternopo & Cherno & Khark & \\
\hline & & Podolskiy & 1 & vtsy & ov & \\
\hline 7. & $\begin{array}{l}\text { Who is considered to be the founder of modern } \\
\text { Olympic Games? }\end{array}$ & 74,2 & 69,3 & 54,1 & 73,9 & 67,9 \\
\hline 8. & $\begin{array}{l}\text { Where the first modern Olympic Games were } \\
\text { conducted? }\end{array}$ & 89,3 & 91,3 & 86,2 & 88,4 & 88,8 \\
\hline 9. & $\begin{array}{l}\text { Ion what year the first Olympic Games were } \\
\text { conducted? }\end{array}$ & 68,3 & 55,8 & 64,2 & 62,2 & 62,6 \\
\hline 10. & Who was the first president of IOC? & 24,5 & 21,3 & 19,8 & 29,1 & 23,7 \\
\hline 11. & Point the name of acting president of IOC & 57,7 & 67,1 & 58,3 & 52,0 & $\mathbf{5 8 , 8}$ \\
\hline 12. & What is the meaning of Olympic rings? & 89,1 & 92,3 & 84,5 & 87,4 & 88,3 \\
\hline 13. & Write please Olympic motto & 88,3 & 92,4 & 81,2 & 87,1 & 87,3 \\
\hline 14. & What is the meaning of concept "Olympism"? & 19,4 & 21,3 & 18,8 & 20,1 & 19,9 \\
\hline 15. & What is Olympic Chart? & 55 & 43,4 & 57,2 & 52,1 & 51,9 \\
\hline 16. & $\begin{array}{l}\text { Where will the next summer Olympic Games be } \\
\text { conducted? }\end{array}$ & 47,9 & 61,1 & 52,7 & 50 & 52,9 \\
\hline 17. & $\begin{array}{l}\text { Where will the next winter Olympic Games be } \\
\text { conducted? }\end{array}$ & 57,2 & 44,7 & 48,9 & 54,2 & 51,2 \\
\hline 18. & $\begin{array}{l}\text { What is the maximal duration of summer Olympic } \\
\text { Games? }\end{array}$ & 28 & 36,1 & 16,3 & 19,1 & 24,8 \\
\hline 19. & In what year was NOC of Ukraine formed? & 80,3 & 65,4 & 74,7 & 78,9 & 74,8 \\
\hline 20. & Who was the first president of NOC of Ukraine? & 73,2 & 70,7 & 63,1 & 74 & $\mathbf{7 0 , 3}$ \\
\hline 21. & $\begin{array}{l}\text { Write please the name of acting president of NOC of } \\
\text { Ukraine }\end{array}$ & 84,2 & 72,1 & 82,1 & 78,3 & 79,2 \\
\hline 22. & $\begin{array}{l}\text { When team of independent Ukraine took part in } \\
\text { summer Olympic Games for the first time? }\end{array}$ & 58,3 & 49,4 & 52,8 & 45,3 & 51,6 \\
\hline 23. & $\begin{array}{l}\text { When team of independent Ukraine took part in } \\
\text { summer Olympic Games for the first time? }\end{array}$ & 68 & 65,2 & 71,3 & 67,8 & 68,1 \\
\hline 24. & $\begin{array}{l}\text { Who became the first Olympic champion of } \\
\text { independent Ukraine at summer Olympic Games? }\end{array}$ & 79,1 & 72,3 & 64,2 & 82,2 & 74,5 \\
\hline 25. & $\begin{array}{l}\text { Who became the first Olympic champion of } \\
\text { independent Ukraine at winter Olympic Games? }\end{array}$ & 58,3 & 52,1 & 62,4 & 57,3 & $\mathbf{5 7 , 9}$ \\
\hline & General indicator \% & 60,1 & 56,0 & 55,1 & 58,1 & 57,4 \\
\hline
\end{tabular}

Analyzing general indicators of correct answers by HEEs we noted the following results: Kamenets-Podolskiy national university, named after Ivan Ogniyenko $-60.1 \%$, Ternopol national pedagogic university, named after Vladimir Gnatiuk - 56\%, Chernovitskiy national university, named after Yuriy Fedkovych - 55,1\%, Kharkov national pedagogic university, named after Grygoriy Skovoroda $-58,1 \%$. It should be noted that difference between indicators is rather insignificant. It confirms low knowledge level of all higher educational establishments' students. 


\section{Discussion}

The results of our research supplemented the data of other authors $[7,8,11,12]$ that main pedagogic specialists in schools' Olympic education system are graduates of specialized higher educational establishments and physical culture faculties of higher educational establishments.

We confirmed the data that system of knowledge in the field of "Olympism" and Olympic movement is an integral part of future physical culture teachers' readiness for schoolchildren's Olympic education.

It brings better results in formation of skills, knowledge and motivation in realization of Olympic education in comprehensive educational establishments.

We confirmed the data about students' low theoretical readiness in the field of Olympic movement $[7,8,11,12]$.

In the process of formation of future physical culture teachers' knowledge system in the field of Olympic education it is necessary to consider theoretical material on Olympic education, which is a part of acting academic programs for 1-4 and 4-11 forms of comprehensive educational establishments.

\section{Conclusions}

Results of our research showed low level of Olympic knowledge system in future physical culture teachers. General indicator of correct answers in the field of history and modern state of Olympic movement was only $57.4 \%$.

Comparison of general indicators of correct answers by every HEE showed that difference between them is insignificant. It confirms insufficient level of students' knowledge in all HEEs, in which the research was conducted. That is why it is rather early to state that training of future physical culture teachers for realization of Olympic education in comprehensive educational establishments is effective.

The further researches will be oriented on perfection of physical culture faculties students' theoretical readiness in the field of Olympism and Olympic movement by introduction of new informational technologies and modern means of education in educational process.

\section{Conflict of interests}

The author declares that there is no conflict of interests.

\section{References:}

1. Bulatova MM. Olimpizm iak universal'na koncepciia vikhovannia ta osviti molodi [Olympism as versatile conception of youth's education and teaching]. Fizichne vikhovannia $v$ shkoli 2008;1(51):40-43. (in Ukrainian)

2. Bulatova MM. Sistema olimpijs'koi osviti v Ukraini ta novi formi ii vprovadzhennia [System of Olympic education in Ukraine and new forms of its implementation]. IX Mizhnarodnij naukovij kongres «Suchasnij olimpijs'kij sport $i$ sport dlia vsikh» [9th International scientific congress "Modern Olympic sports and sports for all"]. Kiev: Olympic Literature; 2005. (in Ukrainian)

3. Bulatova MM. Olimpijs'ka osvita [Olympic education], Kiev; 2002. (in Ukrainian)

4. Bulatova MM. Sistema Olimpijskogo obrazovaniia v Ukraine (1991-2006) [System of Olympic education in Ukraine (1991-2006)]. X Mezhdunarodnoj nauchnyj kongress "Sovremennyj olimpijskij sport i sport dlia vsekh" [10th International scientific congress "Modern Olympic sports and sports for all"], Gdansk; 2006. 38-41. (in Russian)

5. Vaceba OM, Iukhimchuk VP. Aktual'nye voprosy olimpijskogo obrazovaniia v uchebno-vospitatel'nom processe uchenikov obshcheobrazovatel'nykh shkol [Current issues of Olympic education in educational process of comprehensive schools' pupils]. Nauka v olimpijskom sporte 2007;2:87-92. (in Russian)

6. Georgiadis K. Teoreticheskie osnovy olimpijskogo obrazovaniia [Theoretical principles of Olympic education]. Nauka v olimpijskom sporte 2007;2:2-5. (in Russian)

7. Dudkin VIu. Olimpijs'ka osvita v procesi pidgotovki fakhivciv sferi «Fizichne vikhovannia i sport» u specializovanikh vishchikh navchal'nikh zakladakh Ukraini [Olympic education in training of specialists in "Physical education and sports" in specialized higher educational establishments of Ukraine]. Moloda sportivna nauka Ukraini 2009;4:57-61. (in Ukrainian)

8. Iermolova VM. Olimpijs'ka osvita [Olympic education]. Kiev; 2011. (in Ukrainian)

9. Kudriavceva N. Novye formy raboty po olimpijskomu obrazovaniiu detej i molodezhi [New forms of work on Olympic education of children and youth]. Mezhdunarodnyj forum «Molodezh' - Nauka - Olimpizm», Moskva, 14-18 iiulia 1998 g. [International forum "Youth - Science - Olympism", Moscow, July 14-18, 1998], Moscow; 1998. P. 131. (in Russian)

10. Platonov VN, Bulatova MM, Bubka SN. Olimpijskij sport [Olympic sports], Kiev: Olympic Literature; 2009;2. (in Russian)

11. Polikarpova GM. Olimpijskoe obrazovanie i vospitanie kak predmet pedagogicheskogo issledovaniia. Doct. Diss. [Olympic education as the subject of pedagogic study. Doct. Diss.], Velikiy Novgorod; 2003. (in Russian)

12. Ragozina GA. Tekhnologiia podgotovki kadrov dlia realizacii olimpijskogo obrazovaniia detej $i$ uchashchejsia molodezhi. Cand. Diss. [Technology of specialists' training for realization of children and students' Olympic education. Cand. Diss.], Sankt Petersburg; 2002. (in Russian) 
13. Sergeev VN. Olimpijskoe obrazovanie [Olympic education]. Mezhdunarodnyj forum «Molodezh' - Nauka Olimpizm», Moskva, 14-18 iiulia $1998 \mathrm{~g}$. [International forum "Youth - Science - Olympism", Moscow, July 1418, 1998], Moscow; 1988. P. 217-218.

14. Sergeev VN. Gumanisticheskaia napravlennost' realizacii olimpijskogo obrazovaniia. Cand. Diss. [Humanistic orientation of Olympic education realization. Cand. Diss.], [Volgograd; 2000. (in Russian)

15. Solopchuk MS, Bodnar AO. Olimpijs'ka osvita [Olympic education]. Kamenets Podolsky; 2013. (in Ukrainian)

16. Stoliarov VI. Aktual'nye problemy teorii i praktiki olimpijskogo obrazovaniia detej i molodezhi [Current issues of theory and practice of children and youth's Olympic education], Fizicheskaia kul'tura 1998;4:13-19. (in Russian)

17. Diatlenko SM. Fizichna kul'tura v shkoli: 5-11 klasi [Physical culture at school: 5-11 forms], Kiev: Litera; 2011. (in Ukrainian)

18. Diatlenko SM. Fizichna kul'tura v shkoli: navchal'na programa dlia 1-4, 5-9 klasiv [Physical culture at school: 14, 5-11 forms], Kiev: Litera; 2013. (in Ukrainian)

19. Binder DL. Teaching Olympism in schools: Olympic Education as a focus on values education: university lectures on the Olympics. Bellaterra: Centre d'EstudisOlimpics (UAB). International Chair in Olympism (IOC UAB); 2005. Binder DL. Teaching Olympism in schools: Olympic Education as a focus on values education:university lectures on the Olympics. Bellaterra: Centre d'EstudisOlimpics (UAB). International Chair in Olympism (IOC UAB); 2010.

20. Francisco N. Olympic Education in Africa. 5 International Special Session for Presidents and Directors of NOA and Officials of NOC. Ancient Olympia: Greece; 2000. P. 15.

21. Georgiadis K, Syrigos A. Olympic truce sport as a platform for peace. Athens; 2009.

22. Grammatikopoulos V, Hassandra M, Koustelios A,Theodorakis Y. Evaluating the olympic education program: A qualitative approach. Studies in Educational Evaluation, 2005;31(4):347-357.

23. Naul R. Olympism' and education: a critical review. Quest. 2012;64:3:261-264. 


\section{Information about the author: \\ Bondar A.A.; http://orcid.org/0000-0002-8921-3656; alinkabod@gmail.com; Kamenetz-Podolsk National University; st. Ogienko, 61, Kamenetz-Podolsk, Ukraine, Khmelnytsky region, 32300, Ukraine.}

Cite this article as: Bondar A.A. Analysis of Olympic education theoretical readiness of future physical culture teachers. Physical education of students, 2015;6:10-15. http://dx.doi.org/10.15561/20755279.2015.0602

The electronic version of this article is the complete one and can be found online at: http://www.sportpedu.org.ua/html/arhive-e.html

This is an Open Access article distributed under the terms of the Creative Commons Attribution License, which permits unrestricted use, distribution, and reproduction in any medium, provided the original work is properly cited (http://creativecommons.org/licenses/by/4.0/deed.en).

Received: 22.08.2015

Accepted: 29.08.2015; Published: 10.09.2015 